\title{
DYNAMICS OF CHANGES IN MICROORGANISMS IN RHIZOSPHERE ZONE OF LAWN GRASSES IN THE SECOND YEAR AFTER THE APPLICATION OF SEWAGE SLUDGE
}

\author{
Elżbieta Wołejko', Urszula Wydro' ${ }^{1}$,Tadeusz Łoboda' ${ }^{1}$, Jolanta Piekut ${ }^{2}$ \\ 1 Faculty of Civil and Environmental Engineering, Bialystok University of Technology, Wiejska St. 45D, 15-351 \\ Białystok, Poland, e-mail: e.wolejko@pb.edu.pl \\ 2 Department of Agrifood and Forestry Engineering, Bialystok University of Technology, Wiejska St. 45E, 15-351 \\ Białystok, Poland
}

Received: 2015.07.17

Accepted: 2015.08.31

Published: 2015.10.01

\begin{abstract}
The aim of the study was to present the dynamics of changes in the number of selected microorganisms in the rhizosphere zone of grasses two years after the application of sewage sludge. The study was conducted on four specially prepared research plots along the main roads in Bialystok. Three doses of sewage sludge were applied: 0 (control), 7.5 and $15 \mathrm{~kg} / \mathrm{m}^{2}$. Then the plots were seeded with two mixtures of lawn grasses: Eko and Roadside. Samples of roots with soil were collected three times during the vegetation period of 2012 (April, July and October) and assayed for the total number of bacteria, the number of Gram-negative bacteria, the number of Pseudomonas fluorescens, the number of amylolytic and proteolytic bacteria. Microbiological tests of the rhizosphere showed seasonal variations of all investigated microbiological parameters. The greatest average of the total number of bacteria, Gram-negative bacteria and proteolytic bacteria was observed on the plots in April, amylolytic bacteria in July while in the case of Pseudomonas fuorescens was observed on the plots in October. The time of measurement had the biggest impact on the number of microorganisms. An increased number of microorganisms was observed on all plots in April. Whereas, the fertilization with sewage sludge and grass mixtures did not affect the microbiological parameters.
\end{abstract}

Keywords: sewage sludge, grass mixtures, microorganisms, rhizosphere.

\section{INTRODUCTION}

Transportation and its risks cause that urban soil needs constant protection and reclamation treatments because of its progressive chemical degradation, which leads to permanent and progressive deterioration of their properties [Greinert 2000a]. These soils are formed from construction waste, which results in their the compact structure, low humus content and water content as well as a poor biological activity [Greinert 2000b].

In the view of the growing deficit of organic matter in soils, it is necessary to look for other sources of organic matter and nutrients [Gondek and Filipek-Mazur 2005], which would be suitable for fertilization of urban areas. One of interesting aspects is the use of sewage sludge in perennial crops on soils requiring remediation, where gradually releasing nutrients ensure plant growth at a satisfactory level [Kalembasa and Malinowska 2010]. Sewage sludge has different properties, which depend on the quantity and quality of in a view of the growing deficit of organic matter in soils, it is necessary to look for other sources of organic matter and nutrients [Gondek and Filipek-Mazur 2005], which would be suitable for fertilization of urban areas. One of interesting aspects is the use of sewage sludge in perennial crops on soils requiring remediation, where gradually releasing nutrients ensure plant growth at a satisfactory level [Kalembasa and Malinowska 2010]. Sewage sludge has different properties, which depend on the quantity 
and quality of wastewater and the size of the load of pollutants flowing into the treatment plant. The quality of sludge is also influenced by the kind of sewerage system, applied technological parameters, sludge age and the way, in which such deposits are processed, e.g. stabilization and hygienisation [Bień et al 2011, Piekutin 2011].

Organic compounds and minerals including sewage sludge, introduced into the soil, have a significant impact on the number of microorganisms and are transformed by means of enzymes [Sullivan et al 2005]. With regard to Polish regulations [Directive of...2010.], sludge can be used in agriculture and land reclamation for agricultural purposes, without bacteria from the genus Salmonella, and the number of viable eggs of intestinal parasites Ascaris sp., Trichuris sp., Toxocara $s p$. (ATT) in $1 \mathrm{~kg}$ organic dry matter is 0 . In the case of deposits for other purposes, ATT indicator should not exceed 300 in $1 \mathrm{~kg}$ of dry sludge.

The rhizosphere zone is in the region of the most intense biological activity, characterized by a rich bacterial flora and fungi, and it has a great influence on the root nutrients uptake [Jurkiewicz et al. 2004]. Microbial activity plays a very important role in the growth and development of the plant. Plants form soil microflora and influence the microbial transformation constantly taking place in that environment [Wolińska 2010]. According to Głażewska-Maniewska et al. [2004], the microorganisms interact with plants from the germination of the seed until the plant reaches its full maturity, and it can be inert to the plants or to have a beneficial or detrimental effect on their growth. Bien [2002] as well as Krzywy and Iżewska [2004] in their studies also note that among the soil microorganisms are both pathogenic ones, dangerous for humans and the saprophytic, indifferent from the sanitary point of view, but playing an important role in the degradation of pollutants.

The aim of the study was to present the dynamics of changes in the number of selected microorganisms in the rhizosphere zone of grass two years after the application of sewage sludge.

\section{MATERIAL AND METHODS}

The study was conducted at four experimental plots located in the green belts along the main roads in Bialystok (Hetmanska Str., Piastowska Str., Popieluszki Str. and Raginisa Str.), two years after the application of sewage sludge. Each of the test points with an area of $90 \mathrm{~m}^{2}$ was divided into three blocks, which constitued further repetitions. Finally, the entire area surface was divided into 18 objects, each with an area of $5 \mathrm{~m}^{2}(2 \times 2.5$ $\mathrm{m})$. The factors in the experiment were two doses of sludge: 7.5 and $15 \mathrm{~kg} / \mathrm{m}^{2}$ F.M. (approximately 14.5 and $29 \mathrm{t} /$ ha of DM) and one without (control) as well as a mixture of two lawn grasses: Eko from Nieznanice Plant Breeding Station, which contained $30 \%$ of Lolium perenne cv. Niga, $15 \%$ of Poa pratensis cv. Amason, 22.6\% of Festuca rubra cv. Adio and $32.4 \%$ of Festuca rubra cv. Nimba, and grass mixture Roadside from Barenbrug, which contained $32 \%$ of Lolium perenne $\mathrm{cv}$. Barmedia, 5\% of Poa pratensis cv. Baron, 52\% of Festuca rubra rubra cv. Barustic, 5\% of Festuca rubra commutata cv. Bardiva (BE) and 6\% of Festuca rubra commutata cv. Bardiva (NL).

The rhizosphere soil samples for microbiological analyses were collected three times, in April, July and October 2012. The grass mixture roots were taken with soil adhering to them from each test plots. Then, a sample of $5 \mathrm{~g}$ of roots with the soil was suspended in $45 \mathrm{ml}$ of sterile saline solution (solution of $0.85 \% \mathrm{NaCl}$ ) and shaken for $10 \mathrm{~min}$ and then subjected to dispersion. Subsequently, another ten-fold dilutions $\left(10^{-1}-10^{-6}\right)$ and then soil samples were inoculated on the surface of Petri dishes in triplicate on:

- 10\% TSA (Tryptic Soy Agar) medium for determining the total number of bacteria, the bacteria were incubated at $28{ }^{\circ} \mathrm{C}$ for $72 \mathrm{~h}$ [Galimska-Stypa et al. 1999].

- $10 \%$ TSA (Tryptic Soy Agar) medium with crystal violet (solution of $0.1 \%$ ) to determine the number of Gram negative bacteria. The bacteria were incubated at $28^{\circ} \mathrm{C}$ for $72 \mathrm{~h}$ [Galimska-Stypa et al. 1999].

- King B medium with peptone for determining the number of bacteria of the species Pseudomonas fluorescent (the presence of magnesium sulphate in the medium promotes the formation of the characteristic pigmentation by bacteria of the genus Pseudomonas), the bacteria were incubated at $28^{\circ} \mathrm{C}$ for $72 \mathrm{~h}$ [Galimska-Stypa et al. 1999]. The number of fluorescent bacteria Pseudomonas read in a UV light transilluminator, where colonies exhibiting fluorescence were counted.

- Frazier medium with gelatin for determining the number of proteolytic bacteria, which were incubated at $22^{\circ} \mathrm{C}$ for $96 \mathrm{~h}$ [Rodina 1968]. 
- Starch agar (solution of $20 \%$ ) to detemine the number of amylolytic bacteria, which were incubated at $27^{\circ} \mathrm{C}$ for $96 \mathrm{~h}$ to 7 days [Rodina 1968].

The mean number of a colony was expressed as $\mathrm{cfu} \cdot \mathrm{g}^{-1}$ of soil DM.

The statistics of the results was performed by using Statistica 10.0. The tree-way analysis of variance ANOVA analysis was performed to determine the relation between the experiment factors and the number of microorganisms in the rhizosphere zone. In the case of significant F-tests, differences between group means were assessed by the Tukey post hoc test at significance level at $\mathrm{p}<0.05$.

\section{RESULTS AND DISCUSSION}

Before the establishment of the experiment both sewage sludge and soil from each combination were analysed according to the Regulation of the Ministry of Environment of July 13th, 2010 concerning municipal sewage sludge (Table 1). The obtained values of the studied parameters were compared with the values of the Regulation concerning non-agricultural land recultivation [Directive of... 2010].

Sewage sludge used in experiment contained: dry matter $19.3 \%$, organic matter $584.0 \mathrm{~g} / \mathrm{kg} \mathrm{DM}$, $\mathrm{N}-40.0 \mathrm{~g} / \mathrm{kg} \mathrm{DM}, \mathrm{P}-27.0 \mathrm{~g} / \mathrm{kg} \mathrm{DM}, \mathrm{Mg}-7.0$ $\mathrm{g} / \mathrm{kg} \mathrm{DM}, \mathrm{Pb}-2.5 \mathrm{mg} / \mathrm{kg} \mathrm{DM}, \mathrm{Cd}-<0,5 \mathrm{mg} / \mathrm{kg}$ $\mathrm{DM}, \mathrm{Cr}-58 \mathrm{mg} / \mathrm{kg} \mathrm{DM}, \mathrm{Cu}-194 \mathrm{mg} / \mathrm{kg} \mathrm{DM}$, $\mathrm{Ni}-22 \mathrm{mg} / \mathrm{kg} \mathrm{DM}, \mathrm{Zn}-1459 \mathrm{mg} / \mathrm{kg} \mathrm{DM}$ and its $\mathrm{pH}$ was 6.7.

Sewage for reclamation should be stabilized and follow the rules for sanitary and hygienic conditions [Baran 2005]. The addition of sewage sludge into the soil results in enhancement of soil microbial activity and intensive development of the rhizosphere [Joniec and Furczak 2007]. The results indicate that the applied sewage sludge fertilization affected the microbial activity in the rhizosphere zone of the used grass mixtures, but the changes were not statistically significant (Table 2). Sampling time significantly affected the total number of bacteria (at $p<0.05$ ). The largest total number of bacteria was found in April $\left(107.531 \cdot 10^{7} \mathrm{cfu} / \mathrm{g}\right.$ of soil DM), and in July and October, the number of these microorganisms were similar (5.57 and $4.461 \cdot 10^{7} \mathrm{cfu} / \mathrm{g}$ of soil DM respectively). At the beginning of the growing season, in April, the average total number of bacteria in the rhizosphere was the highest when the highest dose of sludge $\left(15 \mathrm{~kg} / \mathrm{m}^{2}\right)$ was used $\left(176.1 \cdot 10^{7} \mathrm{cfu} / \mathrm{g}\right.$ of soil DM) with a mixture of Eco, and the lowest was observed from the plot without the use of sludge $\left(2.7 \cdot 10^{7} \mathrm{cfu} / \mathrm{g}\right.$ of soil DM) with a mixture of Roadside. Generally, the increase in the total number of microorganisms followed increasing doses of sludge (Figure 1). As has been shown in studies by Novák et al. [2007], during the development of soil microorganisms soil nutrients are used, then the products of biochemical changes are collected, which may influence changes in physico-chemical properties of soils, thereby reducing the total number of bacteria in the soil, which could be observed in the present study. In addition, the number of microorganisms in the soil will depend on many factors, i.e. $\mathrm{pH}$ of the soil, air-water relationships, organic matter content, as well as the soil and air temperature [Joniec and Furczak 2007]. According to Gondek [2012], the availability of nutrients from sewage sludge is a function of prevailing climatic conditions during the growing season, the doses of used sludge and the value $\mathrm{C}: \mathrm{N}$ ratio.

Based on the obtained results, one determined a positive effect of doses of sewage sludge on the growth of Gram-negative bacteria in the

Table 1. Selected chemical indicators in the soil samples before the application of sludge

\begin{tabular}{|c|c|c|c|c|c|c|c|c|}
\hline \multirow{2}{*}{ Soil samples } & \multicolumn{7}{|c|}{ Heavy metals content in mg/kg of DM } & \multirow{2}{*}{$\mathrm{pH}$} \\
\hline & $\mathrm{Cd}$ & $\mathrm{Cu}$ & $\mathrm{Ni}$ & $\mathrm{Pb}$ & $\mathrm{Zn}$ & $\mathrm{Hg}$ & $\mathrm{Cr}$ & \\
\hline Popiełuszki Street & 1.65 & 17.9 & 5.89 & 26.5 & 82.4 & 0.14 & 13.1 & 7.35-7.91 \\
\hline Hetmanska Street & $<0.5$ & 9.46 & 4.48 & 12.4 & 40.9 & 0.06 & 10.9 & $7.45-8.16$ \\
\hline Piastowska Street & $<0.5$ & 16.8 & 10.8 & 23.9 & 195 & 0.02 & 13.6 & $7.17-8.29$ \\
\hline Raginisa Street & $<0.5$ & 8.8 & 4.6 & 12.1 & 36.6 & 0.05 & 8.3 & $6.94-8.24$ \\
\hline $\begin{array}{l}\text { The allowed amount of heavy metals in the } \\
\text { surface soil layer (0-25 cm soil light) in the } \\
\text { application of municipal sewage sludge } \\
\text { for land reclamation for non-agricultural } \\
\text { purposes [Directive of...2010] }\end{array}$ & 3 & 50 & 30 & 50 & 150 & 1 & 100 & \\
\hline
\end{tabular}


Table 2. Influence of experiment factors on the average number of selected microorganisms in the rhizosphere zone

\begin{tabular}{|c|c|c|c|c|c|}
\hline Factors & 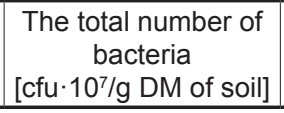 & $\begin{array}{c}\text { The number of Gram } \\
\text { negative bacteria } \\
\text { [cfu } 10^{6} / \mathrm{g} \text { DM of soil] }\end{array}$ & $\begin{array}{l}\text { The number of } P \text {. } \\
\text { fluorescens [cfu- } \\
10^{5} / \mathrm{g} \text { DM of soil] }\end{array}$ & $\begin{array}{c}\text { The number of } \\
\text { amylolytic bacteria } \\
\text { [cfu } 10^{5} / \mathrm{g} \text { DM of soil] }\end{array}$ & $\begin{array}{c}\text { The number of } \\
\text { proteolytic bacteria } \\
\text { [cfu } 10^{6} / \mathrm{g} \text { DM of soil] }\end{array}$ \\
\hline \multicolumn{6}{|c|}{ A-grass mixture } \\
\hline Eco & 44.97 & 31.86 & 8.77 & 46.10 & 16.52 \\
\hline Roadside & 33.40 & 42.06 & 7.99 & 60.86 & 29.49 \\
\hline $\operatorname{NIR}(A)$ & n.s. & n.s. & n.s. & n.s. & n.s. \\
\hline \multicolumn{6}{|c|}{ B - sampling time } \\
\hline April & 107.53 & 57.28 & 9.52 & 76.09 & 35.07 \\
\hline July & 5.57 & 7.31 & 3.87 & 66.06 & 27.84 \\
\hline October & 4.46 & 46.29 & 11.75 & 18.29 & 6.10 \\
\hline $\operatorname{NIR}(B)$ & $69.13^{* *}$ & $39.37^{*}$ & $4.15^{\star *}$ & $41.10^{*}$ & $20.89^{*}$ \\
\hline \multicolumn{6}{|c|}{$\mathrm{C}$ - dose of sewage sludge } \\
\hline Control & 25.84 & 27.72 & 8.12 & 45.43 & 22.60 \\
\hline $7.5 \mathrm{~kg} / \mathrm{m}^{2} \mathrm{FM}$ & 44.67 & 43.09 & 8.49 & 69.87 & 18.92 \\
\hline $15 \mathrm{~kg} / \mathrm{m}^{2} \mathrm{FM}$ & 47.05 & 40.07 & 8.53 & 45.12 & 27.49 \\
\hline NIR (C ) & n.s & n.s. & n.s. & n.s. & n.s. \\
\hline NIR (AxB) & n.s. & n.s. & n.s. & $77.38^{* *}$ & n.s. \\
\hline $\operatorname{NIR}(A x C)$ & n.s. & n.s. & n.s. & n.s. & n.s. \\
\hline NIR $(B x C)$ & n.s. & n.s. & n.s. & n.s. & n.s. \\
\hline
\end{tabular}

* Significant differences at $\mathrm{p}<0.05$; * significant differences at $\mathrm{p}<0.01$; ns - not significant differences.

rhizosphere zone, but this factor did not influence significantly the number of these bacteria (Table 2). In the course of various biochemical processes microbes release metabolites into the soil that modify the conditions and influence the growth of microorganisms that inhabit the area [Durska 2010, Wong et al. 1998]. The average highest number of Gram-negative bacteria in the samples was collected in April at the highest dose of sludge $15.0 \mathrm{~kg} / \mathrm{m}^{2}\left(10.5 \cdot 10^{6} \mathrm{cfu} / \mathrm{g}\right.$ of soil DM) with a mixture of Roadside, and the smallest number of bacteria was obtained for the samples taken in July on the control plots $\left(0.3 \cdot 10^{6} \mathrm{cfu} / \mathrm{g}\right.$ DM of soil) with a mixture of Eco (Figure 1). The factor that significantly influenced the number of Gramnegative bacteria was the time of sampling. There were significant differences between the average number of these bacteria in samples taken in April and July and October and July (Table 2).

Some of the most abundant groups of microorganisms in nature include bacteria of the genus Pseudomonas. These gram-negative bacilli are representatives of the so-called rhizobacteria, which are characterized by forming associations with the roots of plants. These bacteria degrade a variety of sugars, amino acids, alcohols. The representatives of this species can degrade high molecular compounds, e.g. humic acids or pesticides [Krzywy and Iżewska 2004]. Figure 1 shows the effect of the dose of sludge on the number of Pseudomonas fluorescens depending upon the mixture of grasses. However, these factors did not impact significantly of the number of these bacteria. It was found statistically significant differences in the average number of Pseudomonas fluorescens depending on time sampling (Table 2). On average, the biggest number of Pseudomonas fluoerscens was observed on the plots where the soil was fertilized with a dose of $7.5 \mathrm{~kg} / \mathrm{m}^{2}$ and a mixture of Eco and Roadside $\left(12 \cdot 10^{5} \mathrm{cfu} / \mathrm{g}\right.$ DM of soil) and the lowest was collected in July on the control plots (respectively 7 and $6 \cdot 10^{5}$ $\mathrm{cfu} / \mathrm{g}$ DM of soil). Mercado-Blanco et al.[2001] show that some bacteria of the genus Pseudomonas produce diffuse, fluorescent compounds called siderophores that have a high affinity to iron compounds. These species are used for biological control of phytopathogens occurring in the soil [Krzywy and Iżewska 2004]. In addition to the protective function, they may enrich soil with nutrients, plant hormones and vitamins, and increase the bioavailability of these products for plants [Wolińska 2010].

The average number of amylolytic bacteria significantly influenced sampling time. Significant differences between the number of these bacteria in samples collected in April and October, and in July and October were observed (Table 2). 


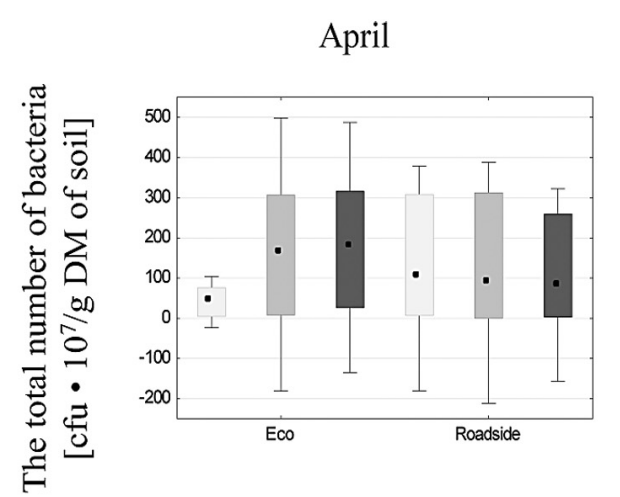

July

October
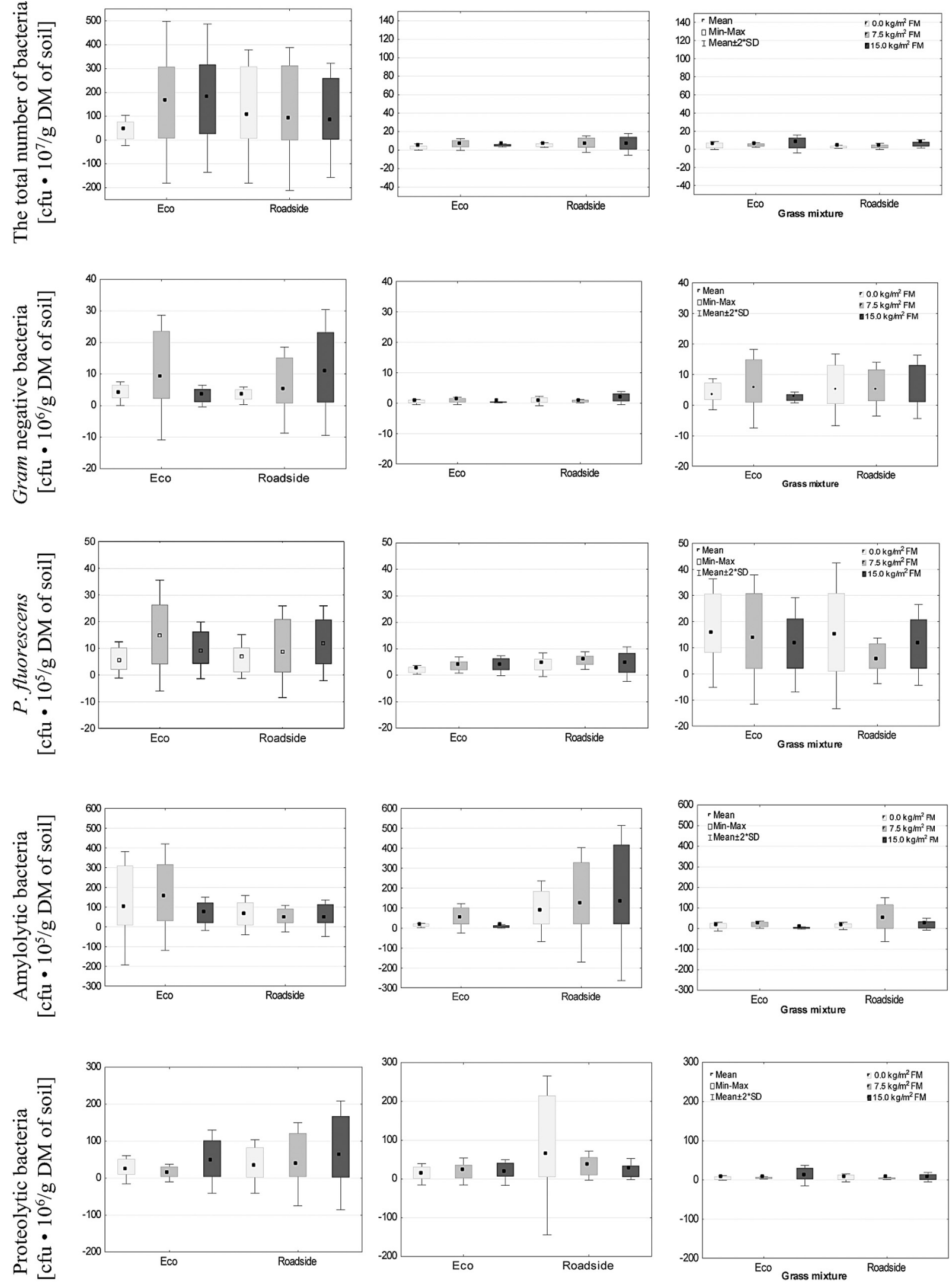

Figure 1. Influence of sewage sludge doses $\left(0,7.5\right.$ and $\left.15 \mathrm{~kg} / \mathrm{m}^{2}\right)$ of the total number of bacteria $\left[\mathrm{cfu} \cdot 10^{7} / \mathrm{g}\right.$ DM of soil], the number of Gram negative bacteria [cfu $10^{6} / \mathrm{g}$ DM of soil], the number of P. fluorescens [cfu $\cdot 10^{5}$ /g DM of soil], amylolytic bacteria[cfu $10^{5} / \mathrm{g}$ DM of soil] and proteolytic bacteria $\left[\mathrm{cfu} \cdot 10^{6} / \mathrm{g} \mathrm{DM}\right.$ of soil] in the rhizosphere zone of grass mixtures (Roadside and Eco) depending on the time of sampling 
In the second year of the experiment the number of amylolytic bacteria ranged from $1.02 \cdot 10^{5} \mathrm{cfu} / \mathrm{g}$ DM of soil (for the samples collected in October from the plots with a double dose of sediment and Roadside grass mixture) to $4.17 \cdot 10^{7} \mathrm{cfu} / \mathrm{g} \mathrm{DM}$ of soil (for the samples collected in July from the plots with a double dose of sediment and Roadside grass mixture). The average largest number of proteolytic bacteria was obtained in July for the samples taken from control plots with a mixture of Roadside $2.15 \cdot 10^{8} \mathrm{cfu} / \mathrm{g}$ DM of soil, and the smallest for the samples taken in October from the plots with a double dose of sediment and Roadside grass mixture $5.21 \cdot 10^{5} \mathrm{cfu} / \mathrm{g}$ DM of soil. The survey conducted by Joniec and Furczak [2007] showed that the addition of sludge to soil influence the growth of microorganisms as well as the biochemical activity of the soil, in particular, in the second year after the application. However, it is not supported by our research, because in the first year after the application of the sludge in the soil microbial activity was more intensive than in the second year, which was shown by Wydro et al. [2015]. There were significant differences between the mean number of bacteria proteolytic October and April and July and October, as in the case of amylolytic bacteria (Table 2).

\section{CONCLUSIONS}

1. Microbiological tests of the rhizosphere in the second year after the application of sewage sludge from the Municipal Wastewater Treatment Plants in Sokółka showed seasonal variations of the total number of bacteria, Gram negative bacteria, Pseudomonas fluorescens, proteolytic bacteria and amylolytic bacteria. The used doses of sewage sludge as well as environmental factors may have resulted in changes in the number of the analyzed bacteria in the rhizosphere.

2. The largest number of Pseudomonas fluorescens and Gram negative was observed in April and October, while the lowest number of bacteria occurred in July, which could be due to the weather conditions.

3. The term of measurement had the biggest impact on the number of microorganisms. An increased number of microorganisms was observed in April on all plots. Whereas, the fertilization with sewage sludge and grass mixtures did not affect the microbiological parameters.

\section{Acknowledgements}

The research presented was supported financially by the project S/WBiIŚ/3/2015 and W/ WBiIŚ/14/2014.

\section{REFERENCES}

1. Baran S., 2005. Zasoby i gospodarka odpadami organicznymi w polsce. In: Kaniuczak J, Kostecka J, Niemiec W. (Ed.). Wybrane aspekty zagospodarowania odpadów organicznych a produkcja biomasy wierzby energetycznej. Rzeszów, Polskie Towarzystwo Inżynierii Ekologicznej, 1, 17-40.

2. Bień J., 2002. Osady ściekowe. teoria i praktyka. Wyd. Politechniki Częstochowskiej, Częstochowa

3. Bień J., Neczaj E., Worwąg M., Grosser A., Nowak D. Milczarek M., Janik M., 2011. Kierunki zagospodarowania osadów w Polsce po roku 2013, Inżynieria i Ochrona Środowiska, 14(4), 375-384.

4. Durska G., 2010. Antagonistyczne interakcje pomiędzy metylotrofami wyizolowanymi z gleby ryzosferowej i pozaryzosferowej jęczmienia oraz innymi mikroorganizmami glebowymi. Nauka Przyroda Technologia, 4(6), 74.

5. Frąc M., Jezierska-Tys S. 2008. Zmiany aktywności mikrobiologicznej gleby brunatnej pod uprawą pszenicy ozimej w różnych latach oddziaływania osadu z oczyszczalni ścieków mleczarskich. Annales Universitatis Mariae Curie-Skłodowska, sec. E, 13(1), 118-132.

6. Galimska-Stypa R., Małachowska-Jutsz A., Mrozowska J., Zabłocka-Godlewska, E., 1999. Laboratorium z mikrobiologii ogólnej i środowiskowej. Mrozowska J. (Ed.). Wydawnictwo Politechniki Śląskiej, Gliwice.

7. Głażewska-Maniewska R., Maciejewska A., Melech A., 2004. Występowanie bakterii glebowych z rodzaju Arthrobacter Spp. w uprawie żyta ozimego oraz ich enzymatyczne i antagonistyczne właściwości. Acta Scientiarum Polonorum Seria Agricultura, 3(1), 129-137

8. Gondek K., 2012. Wpływ nawożenia nawozami mineralnymi, obornikiem od trzody chlewnej i komunalnymi osadami ściekowymi na plon i niektóre wskaźniki jakości ziarna pszenicy jarej (Triticum Aestivum L.). Acta Agrophysica, 19(2), 289-302.

9. Gondek K., Filipek-Mazur B., 2005. Agrochemiczna ocena wartości nawozowej kompostów różnego pochodzenia. Acta Agrophysica, 5(2), 271-282.

10. Greinert A., 2000a. Ochrona i rekultywacja terenów zurbanizowanych. Wyd. Politechniki Zielonogórskiej, Monografia, 97.

11. Greinert A., 2000b. Gleby i grunty miejskie. In: Stan środowiska w zielonej górze w 1999 roku. 
Wojewódzki Inspektorat Ochrony Środowiska, Zielona Góra, 107-117.

12. Joniec J., Furczak J., 2007. Liczebność wybranych grup drobnoustrojów w glebie bielicowej pod uprawą wierzby użyźnionej osadem ściekowym w drugim roku jego działania. Annales Universitatis Mariae Curie-Skłodowska, sec. E, 62 (1), 93-104.

13. Jurkiewicz A., Orłowska E., Anielska T., Godzik B., Turnau K., 2004. The influence of mycorrhiza and EDTA application on heavy metal uptake by different maize varieties. Acta Biologica Cracoviensia Series Botanica, Ser. Bot. 46, 7-18,

14. Kalembasa D., Malinowska E., 2010. Działanie osadu ściekowego na zawartość metali ciężkich w biomasie trawy Miscanthus Sacchariflorus oraz w glebie. Ochrona Środowiska i Zasobów Naturalnych, 42, 198-203.

15. Krzywy E., Iżewska A., 2004. Gospodarka ściekami i osadami ściekowymi. Wyd. Akademii Rolniczej w Szczecinie. Szczecin

16. Mercado-Blanco J., Van Der Drift K.M., Olsson P.E., Thomas-Oates J.E., Van Loon L.C., Bak-Ker P.A., 2001. Analysis of the pms ceab gene cluster involved in biosynthesis of salicylic acid and the siderophore pseudomonine in the biocontrol strain Pseudomonas Fluorescens WCS374. Journal of Bacteriology, 6, 1909-1920.

17. Novák J., Stankovièowá K.,Chlapík J., Labuda R., Jaworekowá S., 2007. Characteristic of eutrophic soils in slovak national parks. Ekológia Trávneho Porastu VII - Medzinárodná Redecká Konferencja, 72-77.

18. Piekutin J., 2011. Zanieczyszczenie wód produktami naftowymi. Rocznik Ochrony Środowiska, 13, 2, 1905-1916.

19. Rodina A., 1968. Mikrobiologiczne metody badania wód. Państwowe Wydawnictwo Rolnicze i Leśne, Warszawa.

20. Rozporządzenie Ministra Środowiska z dnia 13 lipca 2010 r. w sprawie komunalnych osadów ściekowych (Dz.U. 2010 nr 137, poz. 924)

21. Sullivan T.S., Stromberger M.E., Paschke M.W., Ippolito J.A., 2005. Long-term impacts of infrequent biosolids applications on chemical and microbial properties of semiarid rangeland soil. Biology and Fertility of Soils, 42(3), 258-266

22. Wolińska A., 2010, Aktywność dehydrogenazowa mikroorganizmów glebowych i dostępność tlenu w procesie reoksydacji wybranych mineralnych gleb polski. Acta Agrophysica. 180, Rozpr. Monogr. 3

23. Wong J.W.C., Lai K.M., Fang M., Ma K.K., 1998. Effect of sewage sludge amendment on soil microbial activity and nutrient mineralization, Environmental Internaltional, 24(8), 935-943

24. Wydro U., Wołejko E. Łoboda T., Matejczyk M., Butarewicz A., 2015. Influence of sewage sludge on the chosen soil properties and microbiological parameters of urban grass mixtures rhizosphere. Journal of Ecological Engineering, 16(1), 171-177. 